\title{
'Barbary' Mahometans in Early American Propaganda: A Critical Analysis of John Foss's Captivity Account
}

\author{
Saad Boulahnane \\ Department of Religion \& Politics, Ben Msik Faculty \\ of Letters and Humanities \\ Hassan II University, Casablanca, Morocco.
}

\begin{abstract}
This article analyzes the first immigrating images of the North African 'Mahometan' in the American imagination via John Foss's (1798) captivity account. It examines the agenda-led discourses and 'othering' images establishing the ideological split between the notion of the American "us" and the Muslim "them" through various discursive associations in John Foss's (1798) A journal, of the captivity and sufferings of John Foss; several years a prisoner at Algiers: together with some account of the treatment of Christian slaves when sick:-- and observations of the manners and customs of the Algerines. The account's embedded myths, stereotypes, and clichés served as the 'West's' first impression of the Muslim 'corsair'; they rendered more vivid the perceived aberration of the 'Orient;' and they reinforced the symbolism of strength and glory forcefully associated with the newly nascent America. The article further discusses the breadth of circulation and propagation of the constructed 'West-Orient' disparity and the celebration of the confrontation with the 'othered' enemy. American venues-e.g. museums, galleries, and circuses - as well as works of art-e.g. novels, paintings, and cartoons - constituted a major accomplice in the dissemination of the propaganda in the American public space.

Keywords: captivity accounts, Barbary States, North African corsairs, Islamophobia, propaganda, othering

Cite as: Boulahnane, S. (2018). 'Barbary' Mahometans in Early American Propaganda: A Critical Analysis of John Foss's Captivity Account. Arab World English Journal for Translation \& Literary Studies, 2 (1). DOI: http://dx.doi.org/10.24093/awejtls/vol2no1.8
\end{abstract}

